\title{
A Novel Step-Up Austenitization and Austempering Heat Treatment Process for Ductile Cast Iron
}

ISSN: 2576-8840

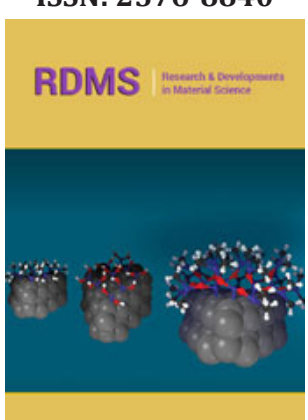

*Corresponding author: Susil K Putatunda, Department of Chemical Engineering and Materials Science, Wayne State University, USA

Submission: 潐 January 03, 2020

Published: 㘹January 10, 2020

Volume 12 - Issue 3

How to cite this article: Deepak J, Susil K P, James B. A Novel Step-Up Austenitization and Austempering Heat Treatment Process for Ductile Cast Iron. Res Dev Material Sci. 12(4).RDMS.000794.2020.

DOI: 10.31031/RDMS.2020.12.000794

Copyright@ Susil K Putatunda, This article is distributed under the terms of the Creative Commons Attribution 4.0 International License, which permits unrestricted use and redistribution provided that the original author and source are credited.

\author{
Deepak Joshi ${ }^{1}$, Susil K Putatunda ${ }^{1 *}$ and James Boileau ${ }^{2}$ \\ ${ }^{1}$ Wayne State University, USA \\ ${ }^{2}$ Ford Motor Company, USA
}

\begin{abstract}
A novel heat treatment process has been conceived for creation of Austempered Ductile Iron (ADI) with combination of high strength and high ductility. The process involves a step up austenitization of ductile cast iron after initial austenitization in the lower intercritical temperature range, then raising the temperature to the fully austenitic region followed by austempering at low bainitic temperatures.

In this investigation an unalloyed ductile cast iron with low Carbon Equivalent (CE) was processed by the conceived novel austempering process. The microstructure and the mechanical properties of the material processed by this technique were characterized by optical metallography, Scanning Electron Microscopy (SEM) and X-ray diffraction. The influence of austempering temperature and time on the microstructure and mechanical properties of this material was also examined.
\end{abstract}

The test results show that resulting microstructure of the material processed by this novel technique consists of very fine scale bainitic ferrite, proeutectoid ferrite and high carbon austenite. ADI with high yield strength and good ductility were obtained as a result of this novel heat treatment process. The mechanical properties were comparable to the conventionally processed ADI (austenitized at fully austenitic temperature range and subsequently austempered at the same austempering temperature and time). However, the ductility was significantly higher than the conventionally processed ADI.

Keywords: Austempered ductile cast iron; Microstructure; Mechanical properties; Austenite; Ferrite; Heat treatment

\section{Introduction}

Austempered Ductile Iron (ADI) has emerged as a very important engineering material in recent years. Ductile cast iron when austenitized and isothermally heat treated in the bainitic temperature range (austempered), it produces a unique microstructure consisting of bainitic ferrite and high carbon austenite. This material is referred to as ADI. ADI is used extensively in many structural applications now a days because of its low production cost, good castability, machinability and excellent mechanical properties [1,2].

The properties of ADI include high strength, good fatigue strength and fracture toughness [1-3]. The conventional heat treatment process for ADI involves following steps; The ductile cast iron is first heated in the fully austenitic region (in the temperature range of $900-950^{\circ} \mathrm{C}$ ) and then quenched in a molten salt bath in the bainitic temperature range of $260-400^{\circ} \mathrm{C}$. After quenching in the bainitic temperature range it is isothermally processed at this temperature for 2 to 4 hours (depending upon the section thickness and chemical composition of the material). A typical conventional austempering heat treatment cycle is shown in Figure 1.

As a result of this heat treatment, ADI undergoes a two-stage phase transformation process. At the first stage the austenite $(\gamma)$ decomposes into bainitic ferrite $(\alpha)$ and high carbon austenite $(\gamma \mathrm{HC})[4,5]$.

$$
\gamma \rightarrow \alpha+\gamma H C
$$

If the casting is held at the austempering temperature for too long, a second stage transformation occurs, where high carbon austenite further decomposes into ferrite and carbide 


$$
\gamma H C \rightarrow \alpha+\varepsilon(2)
$$

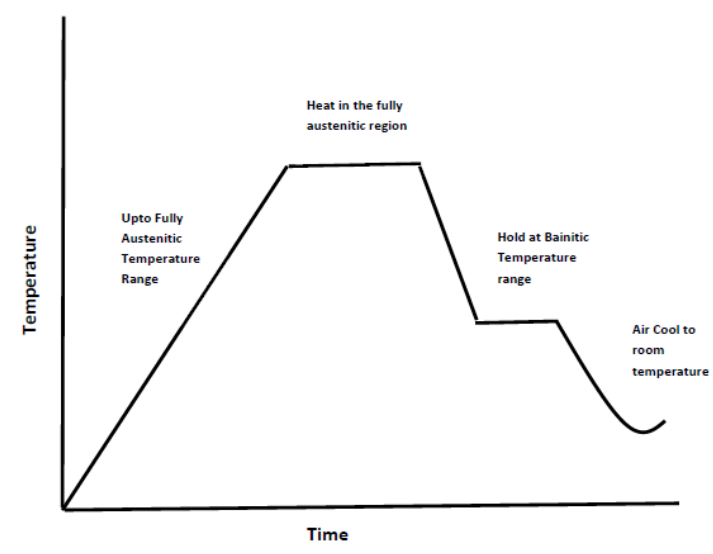

Figure 1: Heat treatment cycle for conventionally processed ADI.

This second reaction is undesirable because it makes the ADI brittle. For desirable properties, the ADI must be austempered in the time period between onset of 1st reaction and before the start of $2^{\text {nd }}$ reaction. This time period between the start of first reaction and onset of second reaction is called process window. This process window depends upon austempering temperature as well as the alloy content of the ductile iron [6]. As a result of this conventional austempering process, the final microstructure in ADI consists of bainitic ferrite and high carbon austenite $(\boldsymbol{\alpha}+\boldsymbol{\gamma H C})$ together with graphite nodules dispersed in the matrix.

The mechanical properties of ADI depend on its microstructure which in turn depends on the austempering time and temperature. When ADI is austempered at lower temperatures (between 260$300{ }^{\circ} \mathrm{C}$ ) it produces a very fine scale microstructure with higher ferrite $(\alpha)$ content and lower volume fraction of austenite $(\gamma)$. This results in high strength but lower ductility in ADI. On the other hand, when ADI is austempered at higher temperatures (300$400{ }^{\circ} \mathrm{C}$ ) it produces a coarser microstructure where ferrite and austenite needles are larger in size and at the same time volume fraction of ferrite is lower in the material (consequently higher volume fraction of austenite).

This coarse microstructure results in lower strength but higher ductility in ADI. Also, the ADI processed at lower temperature has better machinability than ADI austempered at higher temperature. This is due to the fact that ADI austempered at higher temperature contains larger volume fraction of austenite $(\gamma)$ which tend to strain hardens during machining process $[7,8]$.

Based on the above discussion, it is evident that conventionally processed ADI at lower austempering temperature has high strength but low ductility $[9,10]$. On the other hand, ADI must be austempered at higher temperature to have high ductility but will result in lower strength. Thus, a combination of high strength and high ductility is not possible to produce in conventionally processed ADI. Therefore, in recent years many researchers [11-18] have used an intercritical austempering process to improve the ductility of ADI.
In this process, the ductile cast iron is usually heated in the intercritical temperature range (between upper and lower intercritical temperature in iron-carbon diagram where ferrite and austenite coexist) and then austempered. The advantage of this process is that the material contains pro-eutectoid ferrite in the microstructure which results in higher ductility. However, this intercritical austempering results in very low strength in ADI [11] ( in the range of 500-1000MPa).

To overcome these limitations, we have conceived a novel step up austenitization heat treatment process. This involves first heating the ductile iron in the lower intercritical temperature range (where ferrite and austenite coexist) and then raising the temperature to the fully austenitic temperature range (at or above $900{ }^{\circ} \mathrm{C}$ ). This is then followed by austempering. It was theorized by these investigators, that if the ADI is first heated up at the lower intercritical temperature and then heated to the fully austenitic region and then austempered at lower austempering temperatures (e.g. $260^{\circ} \mathrm{C}$ ) it could possibly result in a microstructure consisting of pro-eutectoid ferrite, very fine scale bainitic ferrite $(\alpha)$ and high carbon austenite. A schematic of the proposed heat treatment process is shown in Figure 2. In this case, it will be possible to have a combination of very strength(exceeding $1300 \mathrm{MPa}$ ) and good ductility in ADI (the presence of pro-eutectoid ferrite will enhance the ductility of the material). However, in order to have this microstructure, the pro eutectoid ferrite must not be completely dissolved when ADI is heated in the fully austenitic region. We theorized that if ductile cast iron composition with low carbon equivalent and relatively free from alloying elements is used it could possibly make the transformation reaction of pro-eutectoid ferrite into fully austenitic structure very sluggish and as a result some pro-eutectoid ferrite can be retained in ADI when it is quenched to the bainitic temperature region for isothermal heat treatment. As a result, we should be able to achieve the desired microstructure and consequently the desired mechanical properties in ADI.

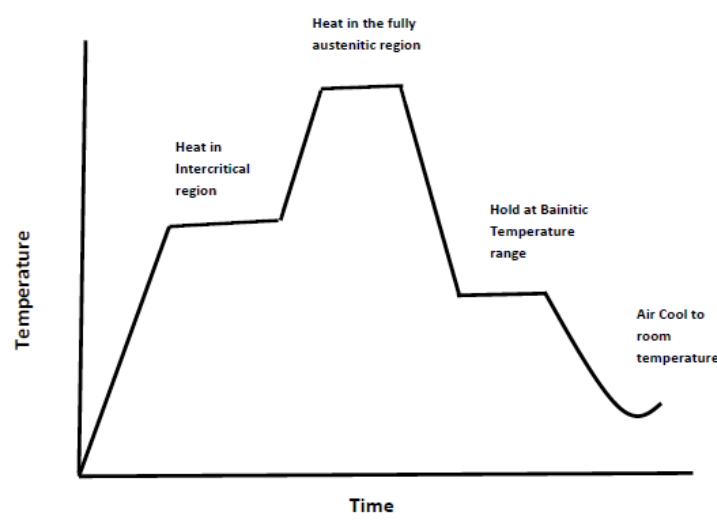

Figure 2: Schematic of the proposed heat treatment Cycle for ADI processed via step up austenitization.

The primary objective of this investigation was to examine the validity of this hypothesis in a low alloy ductile cast iron with low carbon equivalent and to examine whether this step up austenitization is a viable heat treatment process for ADI. The 
secondary objective was to examine the influence of austempering time and temperature on the mechanical properties and microstructure of this material

\section{Experimental Procedure}

\section{Materials}

The material used in this investigation was a ductile cast iron relatively free from alloying elements. The chemical composition of the material in weight percentage is reported in Table 1 . The material was cast in the form of KEEL blocks and from these cast blocks cylindrical tensile samples were machined as per ASTM standards E-8 [19]. In addition, small cubical blocks of samples (0.5"X 0.5"X0.5") were also machined out of the KEEL blocks for heat treatment and microstructural investigation. The carbon equivalent (CE) of the ductile cast iron was calculated using the equation [20]:

$$
C E=\% w t C+0.33(\% S i+\% P)
$$

Table 1: Chemical composition of the material.

\begin{tabular}{|l|l|}
\hline Element & $\mathbf{W t} \%$ \\
\hline $\mathrm{C}$ & 3.44 \\
\hline $\mathrm{S}$ & 0.008 \\
\hline $\mathrm{P}$ & 0.016 \\
\hline $\mathrm{Si}$ & 2.46 \\
\hline $\mathrm{Mn}$ & 0.08 \\
\hline $\mathrm{Cr}$ & 0.05 \\
\hline $\mathrm{Cu}$ & 0.52 \\
\hline $\mathrm{Ni}$ & 1.03 \\
\hline $\mathrm{Mo}$ & $<0.01$ \\
\hline $\mathrm{V}$ & 0.017 \\
\hline $\mathrm{Al}$ & 0.018 \\
\hline $\mathrm{Ti}$ & 0.010 \\
\hline $\mathrm{Mg}$ & 0.043 \\
\hline $\mathrm{Ce}$ & 0.013 \\
\hline
\end{tabular}

The value was determined as $4.25 \mathrm{wt}$. The lower and upper intercritical temperature was determined using an equation that was developed by the Ductile Iron Society and was found to be 780 and $835^{\circ} \mathrm{C}$ respectively [21].

\section{Heat treatment}

Nine batches (A, B, C, D, E, F, G, H and I) of tensile samples were prepared. The details of heat treatment of all these batches are reported in Table 2. Batch A samples were heat treated in the following ways; These samples were processed by step up austenitization process. They were initially austenitized at the lower intercritical temperature of $780{ }^{\circ} \mathrm{C}$ for 90 minutes and then the temperature was increased to $927^{\circ} \mathrm{C}$ and these samples were austenitized at this temperature for 90 minutes. Finally, they were austempered at $260{ }^{\circ} \mathrm{C}$ for 3 hours. In order to verify, whether this process has universal applicability a second batch of samples (Batch B) were also processed by step up austenitization process. Here these samples were initially austenitized at $780{ }^{\circ} \mathrm{C}$ for 90 minutes and then the temperature were raised to $900{ }^{\circ} \mathrm{C}$. These samples were then austenitized at this temperature for 90 minutes and then finally austempered at $260^{\circ} \mathrm{C}$ for 3 hours.

Table 2: Heat treatment process of different batches of ADI.

\begin{tabular}{|c|c|}
\hline Batch & Heat Treatment Cycle \\
\hline A & $\begin{array}{l}\text { Step up Austenitization: } 780 \& 927^{\circ} \mathrm{C} \text { Austemper- } \\
\text { ing: } 260^{\circ} \mathrm{C} \text { for } 3 \text { hours }\end{array}$ \\
\hline $\mathrm{B}$ & $\begin{array}{l}\text { Step up Austenitization: } 780 \& 900^{\circ} \mathbf{C} \\
\text { Austempering: } 260^{\circ} \mathbf{C} \text { for } 3 \text { hours }\end{array}$ \\
\hline $\mathrm{C}$ & $\begin{array}{l}\text { Conventional Austenitization: } 927^{\circ} \mathrm{C} \text { Austemper- } \\
\text { ing: } 260^{\circ} \mathrm{C}\end{array}$ \\
\hline $\mathrm{D}$ & $\begin{array}{l}\text { Step up Austenitization: } 780 \& 927^{\circ} \mathbf{C} \text { Austemper- } \\
\text { ing: } 371 \mathrm{C} \text { for } 3 \text { hours }\end{array}$ \\
\hline $\mathrm{E}$ & $\begin{array}{l}\text { Step up Austenitization: } 780 \& 900^{\circ} \mathbf{C} \text { Austemper- } \\
\text { ing: } 371^{\circ} \mathbf{C} \text { for } 3 \text { hours }\end{array}$ \\
\hline $\mathrm{F}$ & $\begin{array}{l}\text { Conventional Austenitization: } 927^{\circ} \mathbf{C} \text { Austemper- } \\
\text { ing: } 371^{\circ} \mathbf{C} \text { for } 3 \text { hours }\end{array}$ \\
\hline G & $\begin{array}{l}\text { Step up Austenitization: } 780 \& 927^{\circ} \mathbf{C} \text { Austemper- } \\
\text { ing: } 240^{\circ} \mathbf{C} \text { for } 3 \text { hours }\end{array}$ \\
\hline $\mathrm{H}$ & $\begin{array}{l}\text { Step up Austenitization: } 780 \& 927^{\circ} \mathbf{C} \text { Austemper- } \\
\text { ing: } 260^{\circ} \mathbf{C} \text { for } 8 \text { hours }\end{array}$ \\
\hline I & $\begin{array}{l}\text { Step up Austenitization: } 780 \& 900^{\circ} \mathrm{C} \\
\text { Austempering: } 260^{\circ} \mathrm{C} \text { for } 16 \text { hours }\end{array}$ \\
\hline
\end{tabular}

In order to compare the properties and microstructure of samples processed by step up austenitization process with conventionally processed ADI, a third batch of samples (Batch C) were processed by conventional austempering process. These samples were austenitized directly at $927^{\circ} \mathrm{C}$ for 3 hours and then directly austempered at $260^{\circ} \mathrm{C}$ for 3 hours

Samples from batches (D) and (E) were also processed by step austenitization process. Batch D samples were step austenitized at 780 and $927{ }^{\circ} \mathrm{C}$ (like sample A) and batch E samples were step austenitized at 780 and $900{ }^{\circ} \mathrm{C}$ (like sample B) followed by austempering at $371{ }^{\circ} \mathrm{C}$ for 3hours.To compare with these samples batch $\mathrm{F}$ samples were processed through conventional austempering process i.e. directly austenitized at 927 and then austempered at $371{ }^{\circ} \mathrm{C}$ for 3 hours. Another batch of sample $\mathrm{G}$ were processed by step austenitization process like batch $\mathrm{A}$ and then austempered at $240{ }^{\circ} \mathrm{C}$ for 3 hours.This was done to establish the effect of austempering temperature on microstructure and mechanical properties.

Batch $\mathrm{H}$ and I sample were processed by step up austenitization process like batch $\mathrm{A}$ and then austempered at $260{ }^{\circ} \mathrm{C}$ for two different time periods of 8 hours and 16 hours respectively. This was done to examine the effect of austempering time on microstructure and mechanical properties of ADI. 


\section{Microstructural analysis}

The microstructural analysis of the sample was carried out using optical metallography and scanning electron microscopy. The sample were cleaned and polished progressively by 200,400 and 600 grit size Emory papers and then etched with 5\% Nital solution. Prepared samples were examined under optical microscope and JEOL JSM-6510LV-LGS Scanning electron microscope.

\section{Tensile testing}

Tensile tests were carried out on a servo-hydraulic MTS (Material Test System) test machine as per ASTM standard E-8 [19]. At least three samples were tested from each heat-treated condition and the average values are reported in this paper. Load-displacement plots were obtained on an X-Y recorder and yield strength, ultimate tensile strength and percentage elongation values were calculated from these load-displacement diagrams. The average values from three test samples are reported here.

\section{X-ray diffraction}

To determine the volume fraction of constituent phases in the heat-treated samples, X-ray diffraction analysis was performed. Samples of required dimension were cut, grinded and polished. An angular $2 \theta$ range from $42^{\circ}-46^{\circ}$ and $72^{\circ}-92^{\circ}$ was chosen to obtain specific diffraction pattern for the austenite and ferrite peaks [22]. The peaks corresponding to $\left\{\begin{array}{lll}1 & 1 & 1\end{array}\right\}$ and $\left\{\begin{array}{lll}2 & 2 & 0\end{array}\right\}$ planes of FCC austenite and $\left\{\begin{array}{lll}1 & 0\end{array}\right\}$ and $\{211\}$ planes of BCC ferrite were indexed in the diffraction pattern. The volume fractions of ferrite $(\mathrm{X} \alpha)$ and austenite $(X \gamma)$ were determined by the direct comparison of the peak intensity of the indexed planes [23]. The carbon content of the austenite was calculated using the equation [24]

$$
a_{\gamma}=0.3548+0.00441 C_{\gamma}
$$

where $a_{\gamma}$ is the lattice constant and $\mathrm{C}_{\gamma}$ is the carbon content of austenite. The $\{110\}$ and $\{211\}$ planes of austenite were used to measure lattice parameter. The ferritic cell size in the microstructure was determined using the well-known Scherrer equation[23]. A total of three samples were analyzed from each heat-treated conditions and data reported in this paper is the average from these three sample

\section{Results and Discussion}

\section{Influence of Step up austenitization on the microstructure and mechanical properties of ADI}

Microstructure: The optical metallograph of the as cast ductile iron is reported in Figure 3. The microstructure shows a ferritic-pearlitic matrix with graphite nodules dispersed in it. The nodularity of the graphite was $85 \%$ and nodules count was about $125 / \mathrm{cm}^{2}$.

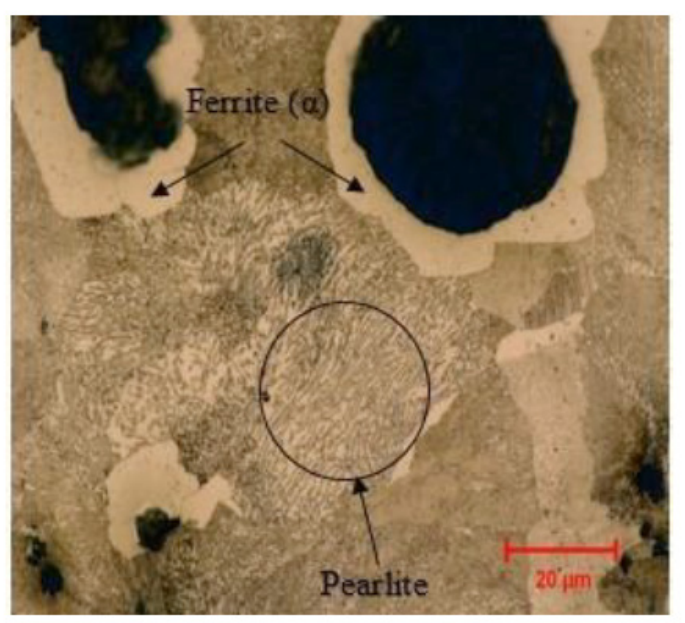

Figure 3: Optical microstructure of the as-cast microstructure of ductile cast iron.

Initially we processed one batch of samples in the fully intercritical region i.e. initially heated in the lower intercritical temperature at $780{ }^{\circ} \mathrm{C}$ and then heated in the upper intercritical temperature at $835^{\circ} \mathrm{C}$ followed by austempering at $260{ }^{\circ} \mathrm{C}$ for 3 hours. The mechanical properties of these samples are reported in Table 3. The yield strength of these samples was low (only $1030 \mathrm{MPa}$ ) and ductility of $3.0 \%$. This did not meet our expectation. While working on this process, we conceived our proposed idea since sufficient strength and ductility is not achievable by processing samples in the fully intercritical temperature range by step up austenitization process.

Table 3: Mechanical properties of intercritically processed ADI.

\begin{tabular}{|c|c|c|c|}
\hline Austempering Temperature $\left({ }^{\circ} \mathbf{C}\right)$ & Yield Strength (MPa) & Tensile Strength (MPa) & \% Elongation \\
\hline 260 & $1030 \pm 66$ & $1378 \pm 67$ & $3.06 \pm 0.75$ \\
\hline
\end{tabular}

The microstructures of ADI processed by step up austenitization process i.e. batch A and B is reported in Figure $4 \mathrm{a} \& 4 \mathrm{~b}$. All these samples were austempered at $260{ }^{\circ} \mathrm{C}$ for 3 hours. Figure $4 \mathrm{c}$ is representation of the microstructure of the conventionally processed samples at $260^{\circ} \mathrm{C}$. It is evident from these micrographs that samples processed by step up austenitization process (Batches A and B) contains pro-eutectoid ferrite, fine scale bainitic ferrite and high carbon austenite. These features are marked in the micrographs. However, the conventionally processed ADI (Batch C) did not have any pro-eutectoid ferrite present in them.

The volume fraction of retained austenite, carbon content of retained austenite (\%) and ferritic cell sizes of all these samples from batches (A, B and C) are reported in Table 4. This table shows that there was no significant difference between these values in samples from batch A and B which indicate no significant change in kinetics of phase transformation occurring during austempering of these samples at the same austempering temperature. 


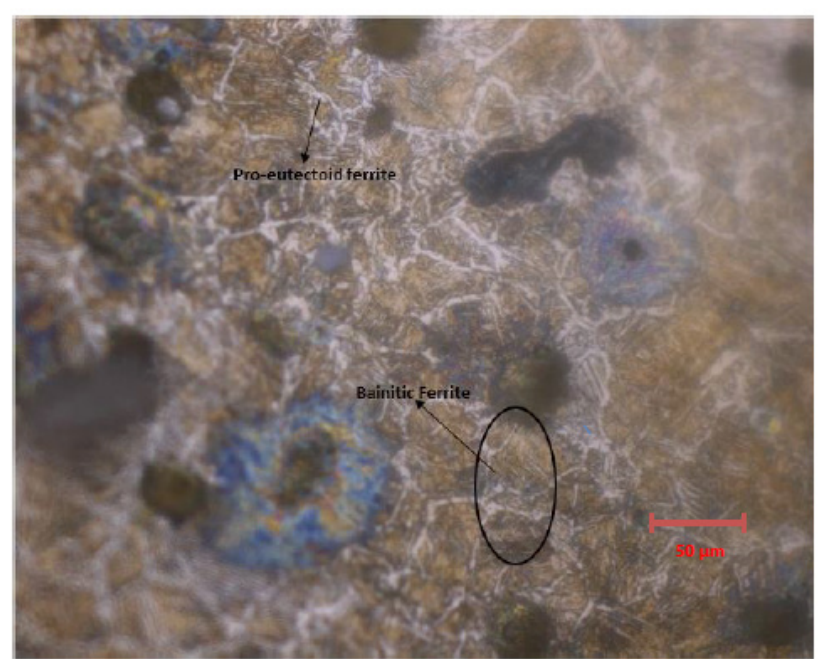

Figure 4a: Microstructure of step up austenitized ADI (Batch A).

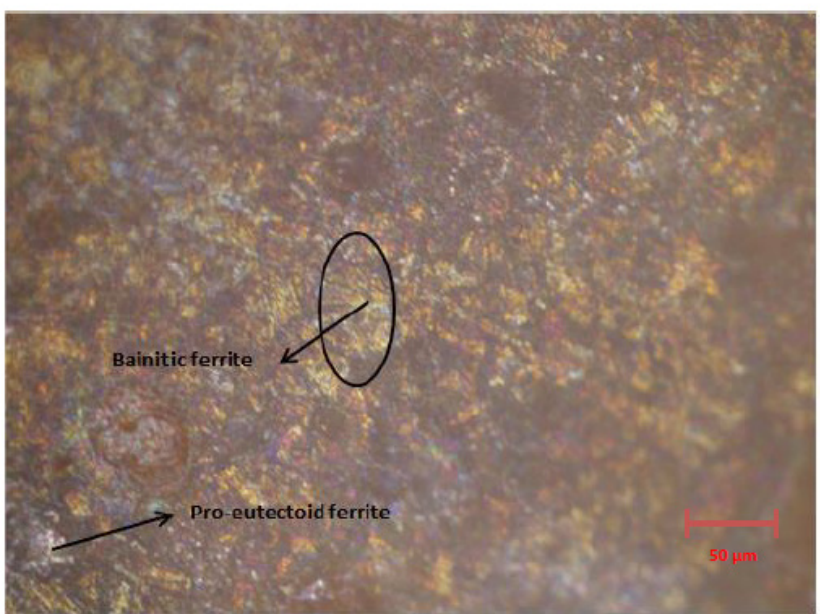

Figure 4b: Microstructure of step austenitized ADI (Batch B).

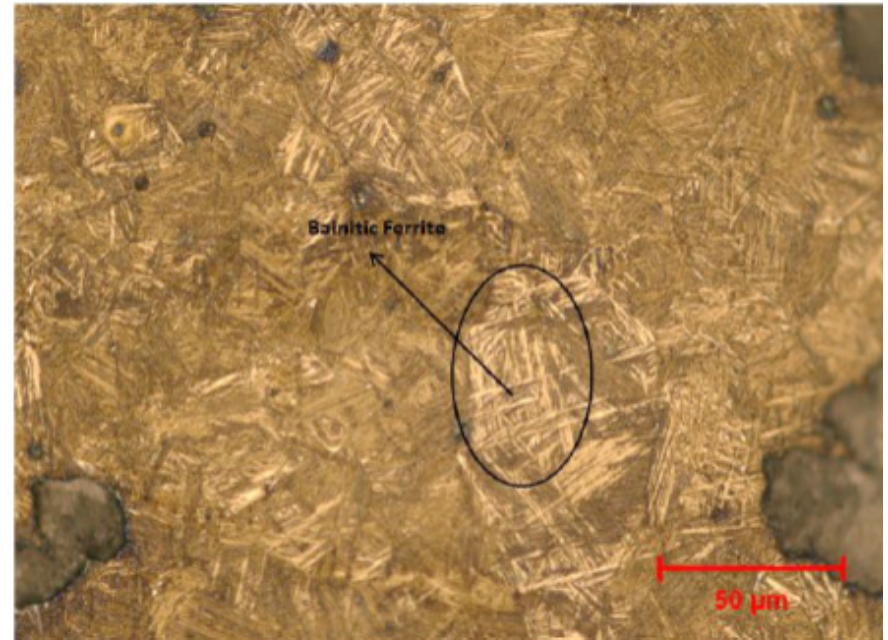

Figure 4c: Microstructure of conventionally processed ADI (Batch C).

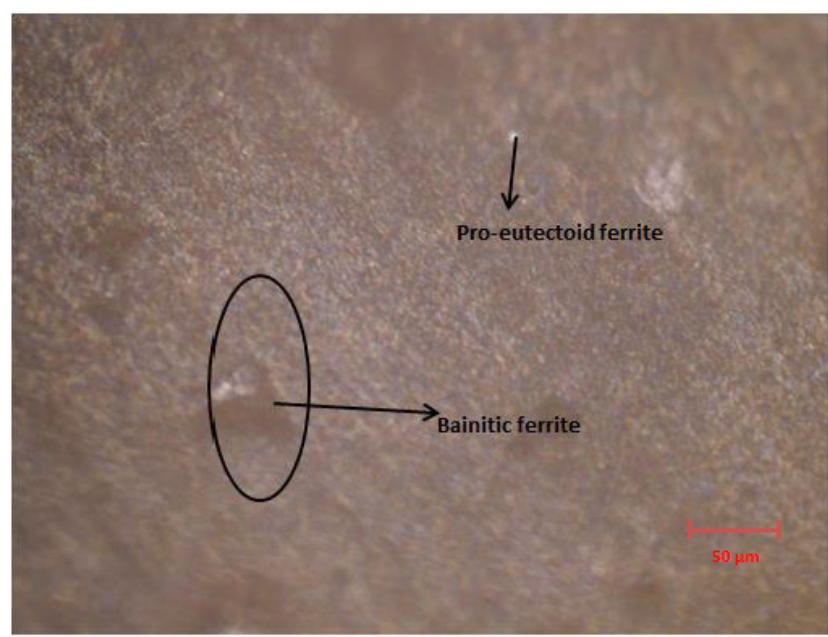

Figure 4d: Microstructure of step up processed ADI (Batch G).

Table 4: Microstructural features of samples of batches A,B and C.

\begin{tabular}{|c|l|l|l|l|c|}
\hline Batch & $\begin{array}{l}\text { Austempering Tempera- } \\
\text { ture } \\
\left({ }^{\circ} \mathbf{C}\right)\end{array}$ & $\begin{array}{l}\text { \% of Austenite } \\
\mathbf{X}_{\gamma}\end{array}$ & $\begin{array}{l}\text { Carbon Content of } \\
\text { Austenite } \\
\mathbf{C}_{\gamma}(\mathbf{w t} \%)\end{array}$ & $\begin{array}{l}\mathbf{X}_{\gamma} \mathbf{C}_{\gamma} \text { (Austenite } \\
\text { Carbon } \\
\text { Content) }\end{array}$ & $\begin{array}{l}\text { Ferritic Cell Size } \\
(\mathbf{n m})\end{array}$ \\
\hline A & 260 & $12.1 \pm 2.1$ & $1.33 \pm 0.15$ & $0.16 \pm 0.003$ & $17.8 \pm 4.4$ \\
\hline B & 260 & $13.6 \pm 2.6$ & $1.39 \pm 0.39$ & $0.19 \pm 0.01$ & $17.6 \pm 0.9$ \\
\hline C & 260 & $7.8 \pm 4.2$ & $1.8 \pm 0.5$ & $0.143 \pm 0.03$ & $17.5 \pm 4$ \\
\hline
\end{tabular}

Mechanical properties: Table 5 reports the mechanical properties of all these samples (Batches A, B and C). It is evident that the yield and tensile strength of the batches $A$ and $B$ samples are comparable to conventional processed (Batch C) samples. However, the ductility of batches A and B samples are higher than the conventionally processed ADI. Thus, it indicates that the step up austenitization and austempering process has indeed resulted in higher ductility but with very comparable strength of conventionally processed ADI and can be considered a viable heat treatment process for ADI. 
Table 5: Comparison of mechanical properties of samples A,B and C.

\begin{tabular}{|l|l|l|l|l|}
\hline Batch & $\begin{array}{l}\text { Austempering Temperature } \\
\left({ }^{\circ} \mathbf{C}\right)\end{array}$ & Yield Strength (MPa) & Tensile Strength (MPa) & \%Elongation \\
\hline A & 260 & $1308 \pm 57$ & $1542 \pm 76$ & $2.73 \pm 0.4$ \\
\hline B & 260 & $1263 \pm 9$ & $1480 \pm 100$ & $2.1 \pm 0.5$ \\
\hline C & 260 & $1390 \pm 28$ & $1594 \pm 21$ & $1.4 \pm 0.1$ \\
\hline
\end{tabular}

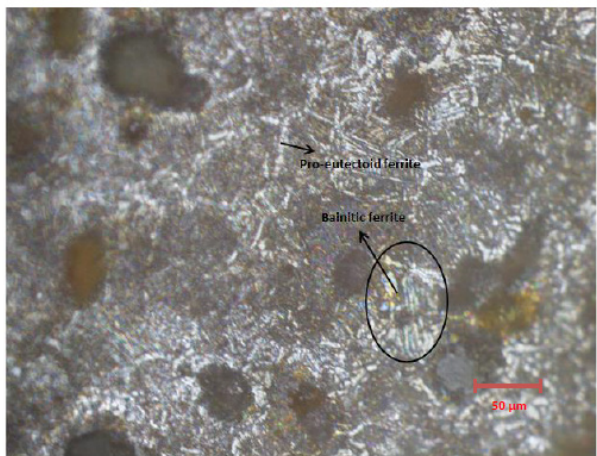

Figure 4e: Microstructure of step austenitized ADI (Batch D).

We once again emphasize that ADI heated in the intercritical region (between 780 and $870{ }^{\circ} \mathrm{C}$ ) will contain pro-eutectoid ferrite and austenite as shown in Figure $5 \mathrm{a}$. After this when the temperature is raised to the fully austenitic region (between $900-927^{\circ} \mathrm{C}$ ) the matrix will have predominantly austenite and some pro-eutectoid ferrite will remain in the microstructure as shown in Figure $5 \mathrm{~b}$. When this mixed microstructure (consisting of undissolved pro-eutectoid ferrite and austenite $(\gamma)$ ) is austempered at low temperature, the austenite $(\gamma)$ will undergo bainitic transformation into ferrite and high carbon austenite $(\gamma \mathrm{HC})$. Because of large super cooling the resulting microstructure is finer in nature which is expected to result in high strength.

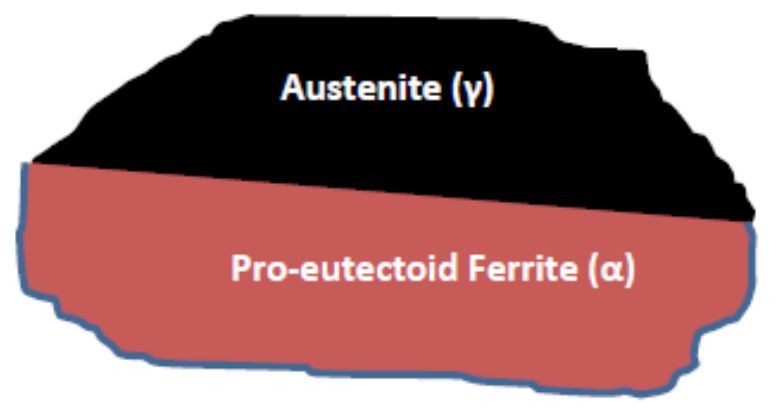

Figure 5a: Microstructure of ductile cast iron at $780^{\circ} \mathrm{C}$.

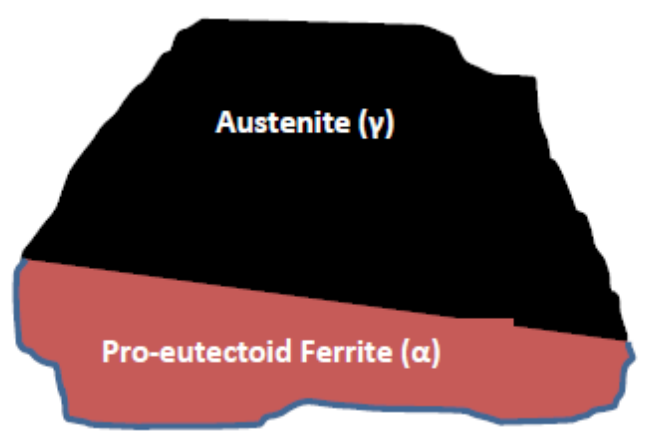

Figure 5b: Microstructure of ductile cast iron at $927^{\circ} \mathrm{C}$.

Table 6: Comparison of mechanical properties of batches D,E and F.

\begin{tabular}{|c|c|c|c|c|}
\hline \multirow{2}{*}{ Batch } & $\begin{array}{c}\text { Austempering } \\
\text { Temperature }{ }^{\circ} \mathbf{C} \text { ) }\end{array}$ & $\begin{array}{c}\text { Yield Strength } \\
\text { (MPa) }\end{array}$ & $\begin{array}{c}\text { Tensile Strength } \\
\text { (MPa) }\end{array}$ & Elongation \\
\hline D & 371 & $847 \pm 13$ & $1106 \pm 27$ & $7.5 \pm 0.7$ \\
\hline E & 371 & $817 \pm 17$ & $1106 \pm 27$ & $4.5 \pm 0.1$ \\
\hline F & 371 & $898 \pm 28$ & $1004 \pm 7$ & $2.8 \pm 1.3$ \\
\hline
\end{tabular}

At the same time, it will also contain some amount of proeutectoid ferrite in the matrix. This combination of pro-eutectoid ferrite and finer content of bainitic ferrite and high carbon austenite provides simultaneous high strength and high ductility.

We further verified our theory by austempering samples (Batch D) at $371^{\circ} \mathrm{C}$. Table $6 \& 7$ also reports the mechanical properties and microstructural features of ADIs austempered at
$371{ }^{\circ} \mathrm{C}$ after processing by step up and conventional austenitization process. On comparison we observe that step up processed ADI possess comparable strength, but higher ductility compared to conventionally processed ADI austempered at $371{ }^{\circ} \mathrm{C}$. The microstructure of ADI processed by step up austenitization and austempered at $371{ }^{\circ} \mathrm{C}$ also shows presence of pro-eutectoid ferrite in its matrix as reported in Figure 4e. 
Table 7: Microstructural features of samples D,E and F.

\begin{tabular}{|l|l|l|l|l|l|}
\hline Batch & $\begin{array}{l}\text { Austempering } \\
\text { Temperature }\left({ }^{\circ} \mathbf{C}\right)\end{array}$ & $\begin{array}{l}\text { \% of } \\
\text { Austenite } \mathbf{X}_{\boldsymbol{\gamma}}\end{array}$ & $\begin{array}{l}\text { Carbon Content } \\
\text { of Austenite } \mathbf{C}_{\boldsymbol{\gamma}}(\mathbf{w t} \%)\end{array}$ & $\begin{array}{l}\mathbf{X}_{\gamma} \mathbf{C}_{\gamma} \text { (Austenite } \\
\text { Carbon Content) }\end{array}$ & $\begin{array}{c}\text { Ferritic } \\
\text { Cell Size (nm) }\end{array}$ \\
\hline D & 371 & $19.1 \pm 4.1$ & $1.7 \pm 0.53$ & $0.33 \pm 0.013$ & $20.3 \pm 2.9$ \\
\hline E & 371 & $16.3 \pm 0.12$ & $1.8 \pm 0.22$ & $0.29 \pm 0.002$ & $16.5 \pm 4.9$ \\
\hline F & 371 & $31.1 \pm 0.12$ & $1.63 \pm 0.8$ & $0.506 \pm 0.002$ & $24.3 \pm 3.3$ \\
\hline
\end{tabular}

It is evident from this discussion that the ADI processed by step up austenitization process results in both high strength and high ductility. While the strength is comparable to conventionally processed ADI ductility was much higher. The presence of proeutectoid ferrite primarily explains the reason for higher ductility in step up austenitized ADI compared to conventionally processed $\mathrm{ADI}$ at the same austempering temperature.

Carbon equivalent of ductile Iron used in this investigation was low (4.25\%) which in turn makes complete phase transformation from proeutectoid ferrite to austenite very sluggish [20] at the fully austenitization temperature i.e. $927^{\circ} \mathrm{C}$ and $900{ }^{\circ} \mathrm{C}$. Moreover, the low alloy content of the of the ductile iron further delays complete transformation of pro-eutectoid ferrite to austenite in step up austenitized ADIs. The combination of these two factors resulted in presence of pro-eutectoid ferrite in samples A, B, D and E.

This study opens up one interesting possibility of creation ADI with similar properties of dual phase steel. Dual phase steel (DP steel) is class of alloy steel with similar structure-property correlation as that of ADI. DP steels possess good combination of strength and toughness which makes them an ideal candidate material for many structural components. The term dual phase steel is used to classify steels which have a mixed microstructure comprising of soft ferrite and hard martensite. The significance of a mixed microstructure in DP steel accounts for their high initial strain hardening rate, high tensile strength, and continuous yield with long and uniform elongation. Previous investigations carried out to study microstructural features in DP steels have reported that the ferrite/martensite phase interface in dual phase steel is highly disorientated with respect to each other which give rise to inherent mobile dislocations $[25,26]$. The presence of high-density mobile dislocation in the crystal structure of dual phase steel is primarily the reason behind their high initial strain hardening rate, uniform elongation and high tensile strength [27].

Previous investigations [25,28] have also shown that change in microstructural feature in DP steels dictates their mechanical properties. These studies have reported that grain refinement in DP steels enhances their strength proportionally as per Hall-Petch relation. The increase in strength due to grain refinement in DP steel has been attributed to the increase in larger phase boundary between ferrite and martensite which in turn leads to evolution of higher mobile dislocation sources. Presence of higher mobile dislocation facilitates higher strain hardening rate and dislocation pile up at ferrite/martensite phase boundary resulting in higher strength. Besides grain size distribution it was also established [29] that equal phase composition of ferrite and martensite in DP steels gives optimum combination of mechanical properties such as high strength and high ductility with good impact toughness. According to these studies the structure-property correlation in DP steels are very similar to the behavior of ADI.

Our present study indicates that it may be possible to crate microstructure similar to dual phase steel in ADI. If the material is processed by step up austenitization like batch A samples and after austempering at low temperature (e.g. $260{ }^{\circ} \mathrm{C}$ ) quenched in water instead of air cooling, the high carbon austenite will convert into martensite. As a result, the final microstructure will have proeutectoid ferrite, fine scale bainitic ferrite and martensite. This combination of microstructure could possibly result in ADI with remarkable combination of very high strength and ductility.

Fine scale ferrite and martensite will provide very high strength and at the same time presence of pro-eutectoid ferrite will impart high ductility. Currently an investigation is in progress to examine this aspect.

\section{Influence of austempering temperature on the microstructure and mechanical properties of ADI.}

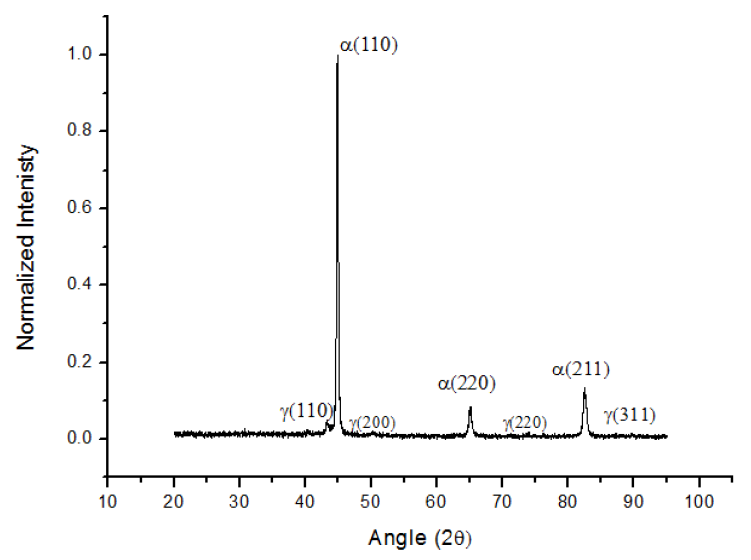

Figure 6: X-ray Diffraction profile of ADI from Batch A.

Microstructure: The optical metallograph of the heat-treated samples austempered at three different temperature (Batch A, G, D) are reported in Figure 4a, 4d \& 4e. These samples were processed by step up austenitization process i.e. initially austenitized at the intercritical temperature of $780^{\circ} \mathrm{C}$ for 90 minutes and then heated up to the fully austenitic temperature of $927^{\circ} \mathrm{C}$ for 90 minutes. This was followed by final austempering at three different temperatures such as $240{ }^{\circ} \mathrm{C}, 260{ }^{\circ} \mathrm{C}$ and $371{ }^{\circ} \mathrm{C}$ for 3 hours. A typical X-Ray Diffraction of these samples is reported in Figure 6. It confirms the presence of both bainitic ferrite $(\alpha)$ and high carbon austenite 
$(\gamma \mathrm{HC})$ in the matrix microstructure. All these microstructures also show the presence of some pro-eutectoid ferrite in the matrix. The microstructural constituents are clearly marked in the metallographs.

The optical metallographs indicate that both ferrite and austenite coarsen with increase in austempering temperature.
This was further verified by determining the ferritic cell size of these samples by X- ray diffraction analysis using Scherer equation [23] and these values are reported in Table 8. It is evident that as the austempering temperature increases the ferritic cell sizes increases which indicate that the ferritic needles coarsen at higher austempering temperature.

Table 8: Influence of austempering temperature on the microstructural features (All samples processed by step up austenitization).

\begin{tabular}{|l|l|l|l|l|c|}
\hline Batch & $\begin{array}{l}\text { Austempering Tempera- } \\
\text { ture } \\
\left({ }^{\circ} \mathbf{C}\right)\end{array}$ & $\begin{array}{l}\% \text { of Austenite } \\
\mathbf{X}_{\gamma}\end{array}$ & $\begin{array}{l}\text { Carbon Content of Aus- } \\
\text { tenite } \\
\mathbf{C}_{\gamma}(\mathbf{w t} \%)\end{array}$ & $\begin{array}{l}\mathbf{X}_{\gamma} \mathbf{C}_{\gamma} \text { (Austenite Carbon } \\
\text { Content) }\end{array}$ & $\begin{array}{l}\text { Ferritic Cell } \\
\text { Size } \\
(\mathbf{n m})\end{array}$ \\
\hline G & 240 & $8.7 \pm 1.8$ & $1.21 \pm 0.13$ & $0.105 \pm 0.0018$ & $15.9 \pm 3.3$ \\
\hline A & 260 & $12.1 \pm 2.1$ & $1.33 \pm 0.15$ & $0.16 \pm 0.003$ & $17.8 \pm 4.4$ \\
\hline D & 371 & $19.1 \pm 4.1$ & $1.7 \pm 0.53$ & $0.33 \pm 0.013$ & $20.3 \pm 2.9$ \\
\hline
\end{tabular}

During austempering process ferrite nucleates at the prior austenite grain boundaries and with rise in temperature these ferritic needles starts growing i.e. coarsening. Since the ferrite dissolves very little carbon the carbon from ferrite also diffuses to surrounding austenite. Thus, carbon content of austenite increases when the austempering temperature increases. The data reported in this table supports this analysis.

Mechanical properties: Table 9 reports the influence of temperature on the mechanical properties of samples from batches A, D and G. The average yield strength of the ADI austempered at $260{ }^{\circ} \mathrm{C}$ was around $1308 \pm 57 \mathrm{MPa}$ whereas it decreased to $847 \pm 13$ MPa for ADI austempered at $371{ }^{\circ} \mathrm{C}$. Similarly, the average tensile strength of the ADI austempered at $260{ }^{\circ} \mathrm{C}$ and $240{ }^{\circ} \mathrm{C}$ remained at $1542 \pm 76 \mathrm{MPa}$ and $1106 \pm 27 \mathrm{MPa}$ respectively. The average $\%$ elongation was measured to be $2.3 \%$ at 260 whereas at $371^{\circ} \mathrm{C}$ it was calculated as $7.5 \%$. Thus, the yield and tensile strength decrease but the ductility increases with increase in austempering temperature. As discussed previously the ferritic cell size of ADI austempered at $260^{\circ} \mathrm{C}$ was smaller than the ADI austempered at $371^{\circ} \mathrm{C}$. The higher yield and tensile strength in ADI at lower austempering temperature was because of finer ferrite and austenite grain size which result in higher strength as per Hall- Petch equation [30,31]. The increase in ductility with increase in austempering temperature is due to two factors a) coarsening of ferritic cell size and b) higher volume fraction of retained austenite.

Table 9: Mechanical properties of sample of batches G,A and D.

\begin{tabular}{|c|c|c|c|c|c|}
\hline Batch & $\begin{array}{c}\text { Austempering Tempera- } \\
\text { ture } \\
\left({ }^{\circ} \mathbf{C}\right)\end{array}$ & $\begin{array}{c}\text { Yield Strength } \\
(\mathbf{M P a})\end{array}$ & $\begin{array}{c}\text { Tensile Strength } \\
\text { (MPa) }\end{array}$ & $\begin{array}{c}\text { \% Elongation } \\
\text { Strain hardening Expo- } \\
\text { nent }\end{array}$ \\
\hline G & 240 & $638 \pm 9$ & $778 \pm 5$ & $0.8 \pm 0.1$ & $0.25 \pm 0.004$ \\
\hline A & 260 & $1308 \pm 57$ & $1542 \pm 76$ & $2.73 \pm 0.45$ & $0.09 \pm 0.007$ \\
\hline D & 371 & $847 \pm 13$ & $1106 \pm 27$ & $7.5 \pm 0.7$ & $0.12 \pm 0.007$ \\
\hline
\end{tabular}

Austenite is a softer phase and thus volume fraction of austenite causes increase in ductility $[4,8-11,17,32]$ have also verified this aspect.

We also expected a higher strength at $240{ }^{\circ} \mathrm{C}$ compared to that at $260^{\circ} \mathrm{C}$ and $371^{\circ} \mathrm{C}$ austempered samples because the ferritic cell size was lower at this temperature. However, the test results show a relatively lower strength at $240^{\circ} \mathrm{C}$. This can be attributed to the fact that two competing process are operating at a given austempering temperature. Even though the ferritic cell size was finer at $240{ }^{\circ} \mathrm{C}$ than at $260^{\circ} \mathrm{C}$ and $371{ }^{\circ} \mathrm{C}$, the austenitic carbon content $\left(\mathrm{X}_{\gamma} \mathrm{C}_{\gamma}\right)$ was lower.
We define here a quantity called as Austenitic Carbon Content $\left(\mathrm{X}_{\gamma} \mathrm{C}_{\gamma}\right)$, a product of austenite content $\left(\mathrm{X}_{\gamma}\right)$ and carbon content of austenite $\left(C_{\gamma}\right)$.This is a measure of toughness of austenite phase $[2,4]$. Higher austenitic carbon will increase the strength and toughness of ADI since it impedes motion of dislocation in austenite $[2,4,8,10,33]$.

Therefore, contribution of $\mathrm{X}_{\gamma} \mathrm{C}_{\gamma}$ to impede dislocation motion is also low. Since the austenite carbon $\mathrm{X}_{\gamma} \mathrm{C}_{\gamma}$ increases with increase in austempering temperature, it will increase the toughness of austenite and the overall strength of ADI. On the other hand, the ferritic cell size increases as austempering temperature increases 
which in turn will tend to decrease its strength. Thus, it can be concluded that for very high strength, ADI should have optimum combination of finer ferritic cell size and higher carbon content in austenite $[2,8,10,33]$. Combination of these two competing factors has resulted in lower strength in $240{ }^{\circ} \mathrm{C}$ than $371{ }^{\circ} \mathrm{C}$ and $260^{\circ} \mathrm{C}$. On the other hand, the strain hardening exponent of sample austempered at $240{ }^{\circ} \mathrm{C}$ was found to be much higher than at 260 ${ }^{\circ} \mathrm{C}$ and $371^{\circ} \mathrm{C}$. In many industrial applications a higher strain hardening (n) exponent where ADI processed at $240^{\circ} \mathrm{C}$ is desirable. Since higher strain hardening exponent means larger uniform deformation in the material during loading, high strain hardening is a highly desirable property for wrought products.

\section{Influence of austempering time on microstructure and mechanical properties of the ADI}

Microstructure: The optical metallographs of the samples that were processed by step up austenitization process and austempered at $260{ }^{\circ} \mathrm{C}$ for 8 hours and 16 hours are reported in Figure 7a \& 7b. The scanning electron micrographs of these samples are reported in Figure 8a, 8b \& 8c.

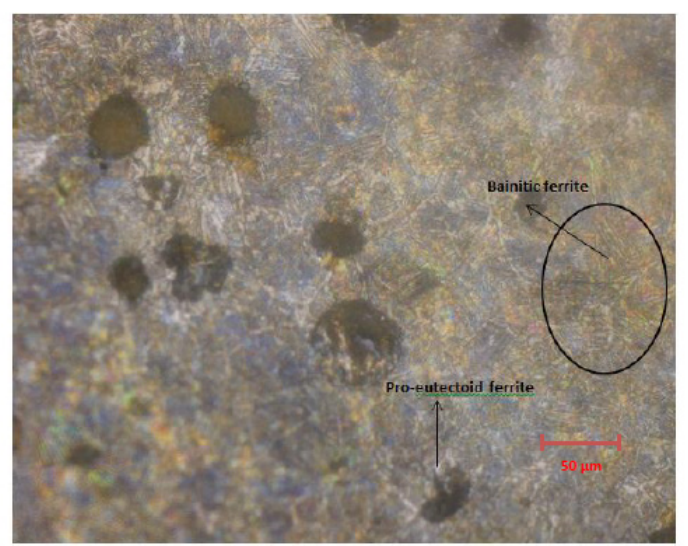

Figure 7a: Microstructure of step-up austenitized ADI (Batch $\mathrm{H})$.

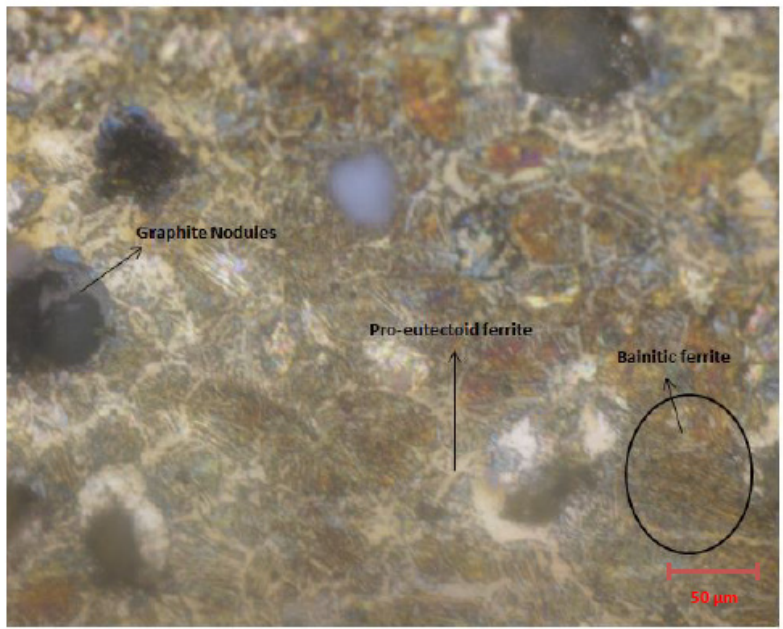

Figure 7b: Microstructure of step-up austenitized ADI (Batch I).

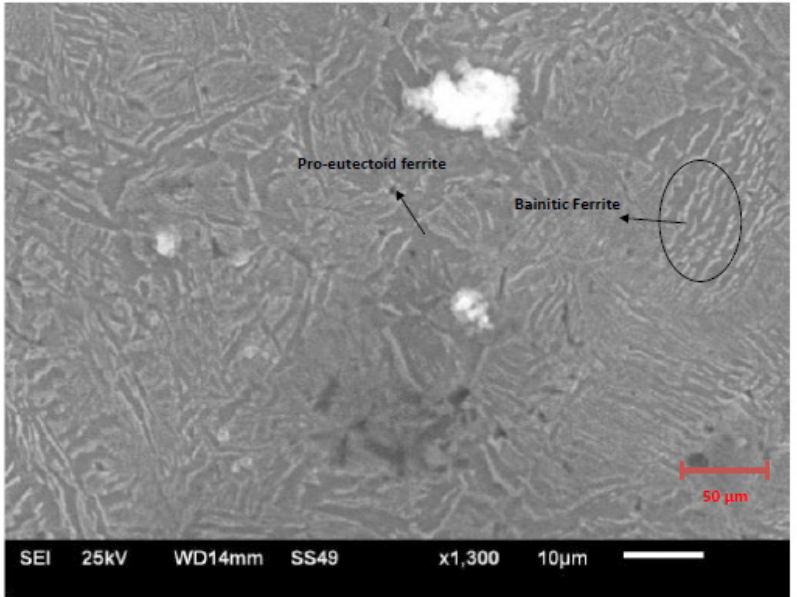

Figure 8a: SEM microstructure of step-up austenitized ADI austempered (Batch A).

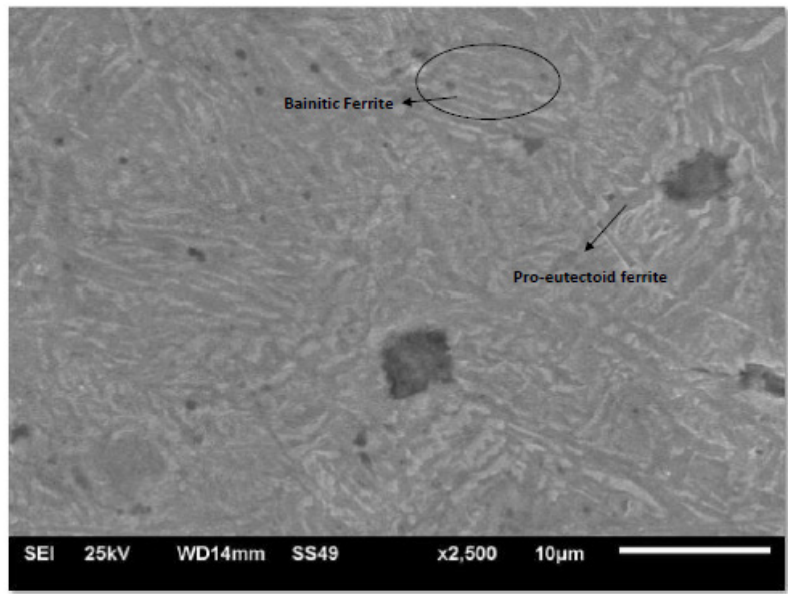

Figure 8b: SEM microstructure of step-up austenitized ADI austempered (Batch $\mathrm{H})$.

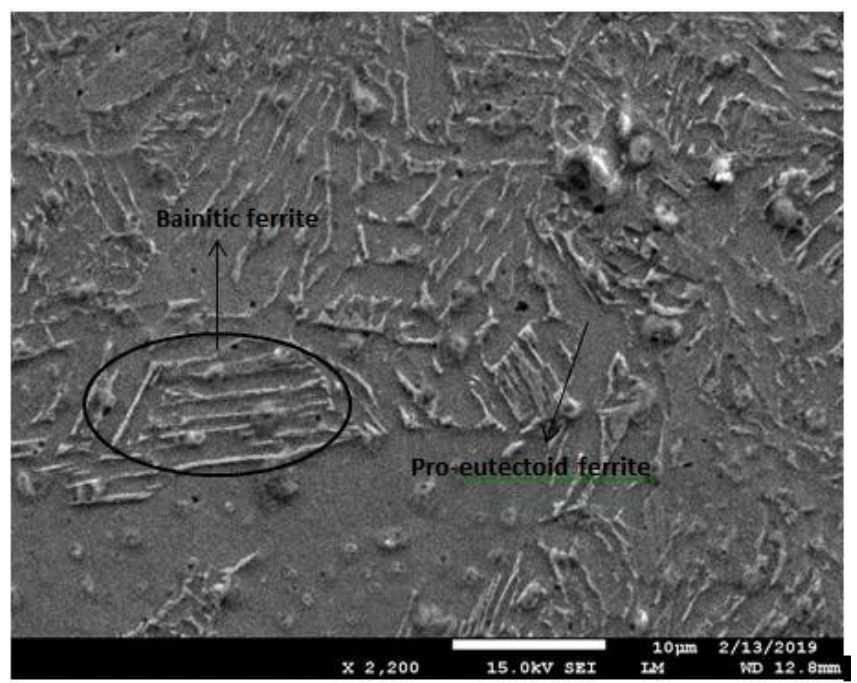

Figure 8C: SEM microstructure of step-up austenitized ADI austempered (Batch I). 
The microstructures of these samples also show presence of pro-eutectoid ferrite, bainitic ferrite and high carbon austenite. All these microstructural constituents are clearly marked in these micrographs. The volume fraction of retained austenite, carbon content of retained austenite and ferritic cell size of these samples (austempered at $260{ }^{\circ} \mathrm{C}$ for 3,8 and 16 hours respectively) is reported in Table 10. It is evident that as the austempering time increases the ferritic cell size increases which indicate that ferrite needles tend to coarsen with increase in austempering time. The ferrite needles initially nucleate at the austenite grain boundaries and as austempering time progresses the ferrite needles starts to grow i.e. coarsens. The growing ferrite needles dissolve very little carbon, so this carbon diffuses out into surrounding austenite. It is evident that as the austempering time increases volume fraction of austenite decreases. This is because of the increase in volume fraction of ferrite with time [34]. The ferrite and austenite volume fraction $\left(X_{\alpha}+X_{\gamma}=\right.$ constant $)$ remain constant at a given austempering temperature.

Therefore, as the volume fraction of ferrite $\left(\mathrm{X}_{\alpha}\right)$ increases, volume fraction of austenite $\left(X_{\gamma}\right)$ should decrease. Our test result confirms this phenomenon.
The carbon content of austenite( $\mathrm{C} 0)$ at any austenitization temperature can be determined by Voigt equation [35]. This was calculated to be equal to $\mathrm{C} 0=0.84 \%$ at $927^{\circ} \mathrm{C}$.This carbon during austempering will be distributed between ferrite and austenite as follows:

$$
C 0=X \alpha C \alpha+X \gamma C \gamma
$$

Where $\mathrm{X}_{\alpha}=$ Volume fraction of ferrite $(\alpha), \mathrm{X}_{\gamma}=$ Volume fraction of retained austenite $(\gamma), C_{\alpha}=$ Carbon content of ferrite $(\alpha)$ and $\mathrm{C}_{\gamma}=$ Carbon Content of austenite $(\gamma)$.

Since ferrite dissolves very little carbon most of this carbon will be with austenite as follows:

$$
C 0=X \gamma C \gamma
$$

Since austenite content $\left(X_{\gamma}\right)$ with time decreases $C_{\gamma}$ must increase. Table 10 indicates that carbon content of austenite increases with time. However, this increase is not very dramatic. This indicates that time has less influence on diffusion of carbon from ferrite to austenite compared to the effect of temperature. Some previous investigations have also confirmed this phenomenon $[34,36]$.

Table 10: Microstructural features of sample of batches A,H and I.

\begin{tabular}{|c|c|c|c|c|c|}
\hline Batch & $\begin{array}{c}\text { Time of Austempering (hours) at } \\
\mathbf{2 6 0}{ }^{\circ} \mathbf{C}\end{array}$ & $\begin{array}{c}\text { \% of Austen- } \\
\text { ite } \mathbf{X}_{\boldsymbol{\gamma}}\end{array}$ & $\begin{array}{c}\text { Carbon Content of Aus- } \\
\text { tenite } \mathbf{C}_{\boldsymbol{\gamma}}(\mathbf{w t} \%)\end{array}$ & $\begin{array}{c}\mathbf{X}_{\gamma} \mathbf{C}_{\gamma} \text { (Austenite } \\
\text { Carbon } \\
\text { Content) }\end{array}$ & $\begin{array}{c}\text { Ferritic Cell } \\
\text { Size (nm) }\end{array}$ \\
\hline A & 3 & $12.1 \pm 2.1$ & $1.33 \pm 0.15$ & $0.16 \pm 0.003$ & $17.8 \pm 4.4$ \\
\hline H & 8 & $12.4 \pm 2.8$ & $1.54 \pm 0.24$ & $0.196 \pm 0.056$ & $19.2 \pm 2.3$ \\
\hline I & 16 & $10.4 \pm 0.5$ & $1.7 \pm 0.16$ & $0.176 \pm 0.024$ & $23.6 \pm 0.7$ \\
\hline
\end{tabular}

Mechanical properties: The mechanical properties of the heat-treated samples from batch A, H and I are reported in Table 11. It is evident from this table that as the austempering time increases both yield strength and tensile strength increases. The ductility of the material on the other hand decreases as the austempering time increases. This increase in yield and tensile strength of ADI with time can be attributed to the increase carbon content of austenite with austempering time. As the carbon content of austenite increases austenite becomes more stronger by solid solution strengthening effect of carbon [2] and movement of dislocation in the material becomes more difficult which inturn increases the strength of the material. The presence of pro-eutectoid in the material has imparted higher ductility in the material.

Table 11: Mechanical properties of sample from batches A,H and I of ADI.

\begin{tabular}{|c|c|c|c|c|}
\hline Batch & Time of Austempering (hours) at $\mathbf{2 6 0}\left({ }^{\circ} \mathbf{C}\right)$ & Yield Strength (MPa) & Tensile Strength (MPa) & \% Elongation \\
\hline A & 3 & $1308 \pm 57$ & $1542 \pm 76$ & $2.73 \pm 0.45$ \\
\hline H & 8 & $1329 \pm 37$ & $1611 \pm 14$ & $3.05 \pm 0.41$ \\
\hline I & 16 & $1469 \pm 20.71$ & $1619 \pm 70$ & $2.3 \pm 0.2$ \\
\hline
\end{tabular}

The conventionally produced ADI has a yield strength of $1390 \pm 28 \mathrm{MPa}$, tensile strength of $1594 \pm 21 \mathrm{MPa}$ and ductility of only $1.4 \pm 0.1$ as reported in Table 2 (batch C) [9,11]. Based on data reported in Table 11 we found that ADI processed by step up austenitization followed by austempering at $260{ }^{\circ} \mathrm{C}$ for 16 hours has a much higher yield strength of $1470 \pm 20.71 \mathrm{MPa}$ and higher ductility of $2.3 \pm 0.2$ compared to conventionally processed ADI.
We attribute the increase in strength and ductility to the higher carbon content in austenite at $260{ }^{\circ} \mathrm{C}\left(\mathrm{X}_{\gamma} \mathrm{C} \gamma\right)$ and presence of proeutectoid ferrite in the ADI processed by step up austenitization. Thus, it appears that the proposed novel process can be a successful austempering process for ADI to obtain higher strength and higher ductility in material. 


\section{Conclusion}

A novel step up austenitization process for Austempered ductile iron was conceived by these investigators. The proposed process was applied in an unalloyed ductile cast iron. Samples were processed at different austempering temperatures and time periods in this investigation.

Following are the main conclusions of this investigation:

1) Low Carbon equivalent (CE) and low alloy ductile iron processed by proposed step up austenitization and austempering results in comparable strength but higher ductility than conventionally processed ADI at the same austempering process

2) The validity of this process was established in three different austempering temperatures.

The high ductility in ADI processed by step up austenitization technique is due to the presence of pro-eutectoid ferrite in the microstructure which indicates complete dissolution of proeutectoid ferrite does not occur during step up austenitization in the fully austenitic temperature. This opens up the possibility that with proper selection of alloy chemistry and austempering process ADI with very high strength and very high ductility could be obtained. We recommend further investigation in this area.

3) ADI samples processed by step up austenitization and austempering for longer period at $260^{\circ} \mathrm{C}$ has resulted in very high strength along with good ductility.

4) The effect of austempering temperature on ADI showed an increase in strength for ADI austempered at $260{ }^{\circ} \mathrm{C}$ to ADI austempered at $371{ }^{\circ} \mathrm{C}$ because of a finer grain structure. The strength of ADI austempered at $240{ }^{\circ} \mathrm{C}$ did not follow the expected trend but was found to be lower than ADI austempered at 260 and $371^{\circ} \mathrm{C}$. This decrease is associated to the lower carbon content of retained austenite $\left(X_{\gamma} C_{\gamma}\right)$ in ADI austempered at 240 than at 260 and $371^{\circ} \mathrm{C}$.

5) ADI processed by step up austenitization and austempered at $240{ }^{\circ} \mathrm{C}$ had significantly higher strain hardening exponent. The higher strain hardening exponent is a desirable feature in many industrial applications because of larger uniform deformation in high strain hardening materials.

6) ADI processed via step up austenitization and austempered at $260{ }^{\circ} \mathrm{C}$ for 16 hours had very high strength and higher ductility compared to conventionally processed ADI austempered at $260{ }^{\circ} \mathrm{C}$ for 3 hours. The higher overall strength and ductility is attributed to higher carbon content in retained austenite $\left(\mathrm{X}_{\gamma} \mathrm{C}_{\gamma}\right)$ and presence of pro-eutectoid ferrite in ADI processed by step up austenitization compared to conventionally processed ADI.

\section{References}

1. Gundlach RB, Janowakm JF (1985) Austempered ductile iron combines strength with toughness and ductility. Metal Progress 128(2): 19-26.

2. Rao PP, Putatunda SK (1998) Dependence of fracture toughness of austempered ductile iron on austempering temperature. Metallurgical and Materials Transactions a-Physical Metallurgy and Materials Science 29(12): 3005-3016.

3. Harding RA (2007) The production, properties and automotive applications of austempered ductile iron. Kovove Materialy-Metallic Materials 45(1): 1-16.

4. Putatunda SK, Kesani S, Tackett R, Lawes G (2006) Development of austenite free ADI (austempered ductile cast iron). Materials Science and Engineering a-Structural Materials Properties Microstructure and Processing 435: 112-122.

5. Trudel A, Gagne M (1997) Effect of composition and heat treatment parameters on the characteristics of austempered ductile irons. Canadian Metallurgical Quarterly 36(5): 289-298.

6. Bayati H, Elliott R (2016) The concept of an austempered heat treatment processing window. International Journal of Cast Metals Research 11(5): 413-417.

7. Kilicli V, Erdogan M (2008) The strain-hardening behavior of partially austenitized and the austempered ductile irons with dual matrix structures. Journal of Materials Engineering and Performance 17(2): 240-249.

8. Yang J, Putatunda SK (2004) Influence of a novel two-step austempering process on the strain-hardening behavior of austempered ductile cast iron (ADI). Materials Science and Engineering a-Structural Materials Properties Microstructure and Processing 382(1-2): 265-279.

9. Panneerselvam S, Martis CJ, Putatunda SK, Boileau JM (2015) An investigation on the stability of austenite in Austempered Ductile Cast Iron (ADI). Materials Science and Engineering a-Structural Materials Properties Microstructure and Processing 626: 237-246.

10. Yang JH, Putatunda SK (2004) Improvement in strength and toughness of austempered ductile cast iron by a novel two-step austempering process. Materials \& Design 25(3): 219-230.

11. Panneerselvam S, Putatunda SK, Gundlach RB, Boileau JM (2017) Influence of intercritical austempering on the microstructure and mechanical properties of austempered ductile cast iron (ADI). Materials Science and Engineering a-Structural Materials Properties Microstructure and Processing 694: 72-80.

12. Ovali I, Kilicli V, Erdogan M (2013) Effect of microstructure on fatigue strength of intercritically austenitized and austempered ductile irons with dual matrix structures. ISIJ International 53(2): 375-381.

13. Basso A, Caldera M, Massone J (2015) Development of high silicon dual phase austempered ductile iron. ISIJ International 55(5): 1106-1113.

14. Basso A, Martinez R, Sikora J (2011) Influence of chemical composition and holding time on austenite (gamma) -> ferrite (alpha) transformation in ductile iron occurring within the intercritical interval. Journal of Alloys and Compounds 509(41): 9884-9889.

15. Murcia SC, Paniagua MA, Ossa EA (2013) Development of as-cast dual matrix structure (DMS) ductile iron. Materials Science and Engineering a-Structural Materials Properties Microstructure and Processing 566: 8-15.

16. Aranzabal J, Serramoglia G, Rousiere D (2003) Development of a new mixed (ferritic- ausferritic) ductile iron for automotive suspension parts. International Journal of Cast Metals Research 16(1-3): 185-190.

17. Kilicli V, Erdogan M (2006) Tensile properties of partially austenitised and austempered ductile irons with dual matrix structures. Materials Science and Technology 22(8): 919-928.

18. Basso A, Sikora J (2012) Review on production processes and mechanical properties of dual phase austempered ductile iron. International Journal of Metalcasting 6(1): 7-14.

19. ASTM-E8 (2013) Standard test methods for tension testing of metallic materials. West Conshohocken, USA. 
20. Reed-Hill RE. Physical metallurgy principles ( $\left.4^{\text {th }} \mathrm{edn}\right)$.

21. Myszka D, Borowski T, Babul T (2007) Influence of cryogenic treatment on microstructure and hardness of austempered ductile iron. Proceedings of the $5^{\text {th }}$ IASME/WSEAS International Conference on Heat Transfer 2007: 123-128.

22. Rundman KB, Klug RC (1982) An x-ray and metallographic study of austempered ductile cast iron. Am Foundry Soc Trans 90: 499-508.

23. Cullity BD (1974) Elements of X-ray diffraction. MA, USA.

24. Roberts CS (1982) Effect of carbon on the lattice parameter of austenite. Trans AIME 197: 203-204.

25. Calcagnotto M, Adachi Y, Ponge D, Raabe D (2011) Deformation and fracture mechanisms in fine- and ultrafine-grained ferrite/martensite dual-phase steels and the effect of aging. Acta Materialia 59(2): 658-670.

26. Park KT, Lee YK, Shin DH (2005) Fabrication of ultrafine grained ferrite/martensite dual phase steel by severe plastic deformation. ISIJ International 45(5): 750-755.

27. Calcagnotto M, Ponge D, Raabe D (2008) Ultrafine grained ferrite/ martensite dual phase steel fabricated by large strain warm deformation and subsequent intercritical annealing. ISIJ International 48(8): 10961101.

28. Calcagnotto M, Ponge D, Raabe D (2010) Effect of grain refinement to $1 \mathrm{mu}$ m on strength and toughness of dual-phase steels. Materials Science and Engineering a-Structural Materials Properties Microstructure and Processing 527(29-30): 7832-7840.
29. Bag A, Ray KK, Dwarakadasa ES (1999) Influence of martensite content and morphology on tensile and impact properties of high-martensite dual-phase steels. Metallurgical and Materials Transactions a-Physical Metallurgy and Materials Science 30(5): 1193-1202.

30. Dieter GE (1986) Mechanical metallurgy. McGraw Hills, USA.

31. Hall EO (1951) The deformation and ageing of mild steel- discussion of results. Proceedings of the Physical Society of London Section B 64(381): 747-753.

32. Voigt RC (1989) Austempered ductile iron-processing and properties. Cast Metals 2(2): 71-93.

33. Putatunda SK (2001) Development of austempered ductile cast iron (ADI) with simultaneous high yield strength and fracture toughness by a novel two-step austempering process. Materials Science and Engineering a-Structural Materials Properties Microstructure and Processing 315(1-2): 70-80.

34. Putatunda SK, Gadicheria PK (2000) Effect of austempering time on mechanical properties of a low manganese austempered ductile iron. Journal of Materials Engineering and Performance 9(2): 193-203.

35. Dorazil E (1986) Mechanical properties of austempered ductile iron. Foundry Mangement and Technology, pp: 36-45.

36. Dias JF, Ribeiro GO, Carmo DJ, Vilela JJ (2012) The effect of reducing the austempering time on the fatigue properties of austempered ductile iron. Materials Science and Engineering a-Structural Materials Properties Microstructure and Processing 556: 408-413.

For possible submissions Click below: 